\title{
Interaction between succinylcholine and cimetidine in rats
}

The hypothesis that histamine $\mathrm{H}_{2}$ receptor blockade adversely affects neuromuscular function was tested, in vivo, in rats anaesthetised with urethane during mechanical pulmonary ventilation. Succinylcholine was administered as a bolus and constant-rate infusion to maintain $49.2 \%( \pm 1.5$ SEM) twitch suppression in 19 rats. Cimetidine iv, 3.2, 7.5. 10, 17.8, 23.7, 31.6 , or $56.2 \mathrm{mg} \cdot \mathrm{kg}^{-1}$ was then administered in groups of two to three rats. Cimetidine produced an immediate potentiation of twitch suppression followed by a transient reversal and then $a$ continued potentiation. Peak potentiation occurred within 19.0 $( \pm 2.7) \mathrm{sec}$ and was maintained in 11 rats at steady-state. Reversal was evident $4.1( \pm 0.4) \mathrm{min}$ after cimetidine administration. There was a good relationship between peak potentiation and serum cimetidine concentration with $50 \%$ potentiation occurring at $46.5( \pm 4.6) \mu \mathrm{g} \cdot \mathrm{ml}^{-1}$. Potentiation at steady-state was not correlated to serum cimetidine concentration but there was a weak relationship between reversal and serum cimetidine concentration. These results support reports from patients of an interaction between cimetidine and succinylcholine.

L'hypothèse voulant que le blocage de récepteurs histaminiques de type $\mathrm{H}_{2}$ affecte la fonction neuromusculaire a été vérifiée in vivo sur des rats anesthésiés avec de l'uréthane et ventilés artificiellement. Chez 19 rats, un bolus de succinylcholine suivi d'une perfusion constante ont été administrés de façon à maintenir une dépression du " twitch "de 49,2\% ( $\pm 1,5$ SEM). Chez des groupes deux ou trois rats, de la cimétidine a alors été administrée par voie intraveineuse à raison de $3,2,7,5,10,17,8$, $23,7,31,6$, ou $56,2 \mathrm{mg} \cdot \mathrm{kg}^{-1}$. La cimétidine a produit une

\section{Key words}

NEUROMUSCULAR RELAXANTS: succinylcholine; HISTAMINE: cimetidine;

PHARMACOLOGY: interaction.

From the Pharmacy Department, The University of Sydney, New South Wales, Australia.

Address correspondence to: Dr. I. Ramzan, Pharmacy Department, The University of Sydney, New South Wales 2006, Australia.

This project was supported in part by financial assistance from the Pharmacy Research Trust of New South Wales.

Accepted for publication 6th December, 1991.
Yogendra Mishra M Pharm, Iqbal Ramzan PhD

potentialisation immédiate de la dépression du " twitch » suivie d'une récupération transitoire puis d'une potentialisation soutenue. La potentialisation maximale est survenue en 19,0 $( \pm 2,7)$ sec et s'est maintenue à un niveau stable chez 11 rats. La récupération était évidente $4,1( \pm 0,4)$ min après l'administration de cimétidine. Il y avait une bonne relation entre la potentialisation maximale et la concentration sérique de cimétidine avec une potentialisation de $50 \%$ survenant à $46,5( \pm 4,6)$ $\mu \mathrm{g} \cdot \mathrm{ml}^{-1}$. Le degré de potentialisation soutenue à un niveau stable n'était pas corrélatif à la concentration sérique de cimétidine mais il y avait une faible relation entre la récupération et la concentration sérique de cimétidine. Ces résultats supportent les rapports d'une interaction entre la cimétidine et la succinylcholine chez les humains.

There are widespread indications for the use of $\mathrm{H}_{2}$ receptor antagonists in anaesthetic practice. These agents are used routinely to increase $\mathrm{pH}$ and decrease the volume of gastric contents before induction of anaesthesia.' Also, it has been suggested that $\mathrm{H}_{2}$ (and $\mathrm{H}_{1}$ ) antagonists be used to prevent cardiovascular changes occurring during the administration of drugs which release histamine, e.g., certain neuromuscular blockers. ${ }^{2}$

Cimetidine, the prototypic $\mathrm{H}_{2}$ antagonist, has been the most commonly used agent as premedication to reduce aspiration pneumonitis. ${ }^{3}$ For this purpose, cimetidine, 150 to $300 \mathrm{mg}$ is administered the night before surgery and one to two hours before induction of anaesthesia. Since cimetidine exhibits diverse cholinergic effects including an anti-cholinesterase and a neuromuscular blocking effect, ${ }^{4}$ there is the potential for interaction between cimetidine and the neuromuscular blocking drugs administered to facilitate intubation and to maintain muscle relaxation during surgery. The effect of cimetidine on the action of the depolarizing (non-competitive) neuromuscular blocker, succinylcholine, has not attracted detailed systematic attention but one study has shown that cimetidine prolongs the duration of action of this neuromuscular blocker. However, two other studies, also in patients, did not reveal any changes in the duration of action of succinylcholine in the presence of cimetidine. ${ }^{6.7}$ Therefore, the present study was designed to examine the potential interaction between 
succinylcholine and cimetidine and to test the hypothesis that $\mathrm{H}_{2}$ receptor blockade with cimetidine adversely affects neuromuscular function during anaesthesia.

\section{Methods}

\section{Anaesthesia and surgical preparation}

The protocol was reviewed and approved by the Animal Care and Use Committee of The University of Sydney. Twenty-three male Sprague-Dawley rats (University of Sydney Animal Services) weighing 304-556 g were used. Anaesthesia was induced with diethyl ether and maintained throughout the experiment with $i v$ urethane, 1.25 $\mathrm{g} \cdot \mathrm{kg}^{-1}$ in total, given as six divided doses during the surgical preparation of the animal. Rectal temperature was servo-controlled to about $38^{\circ} \mathrm{C}$ with a heated surgical table and a heat lamp.

The surgical preparation consisted of cannulation of both jugular veins and a carotid artery. The right jugular vein was for administration of urethane and cimetidine and the left for the administration of the neuromuscular blocker. Blood samples for drug assay were obtained from the carotid artery cannula. Following the vascular cannulations, a tracheostomy was performed and the lungs were ventilated mechanically with room air. A sciatic nerve in the thigh was then isolated and stimulated electrically using supramaximal stimuli of 2 volts with a duration of $0.2 \mathrm{msec}$ at a frequency of $0.1 \mathrm{~Hz}$. The mechanical twitch response of the isolated tibialis anterior muscle was then measured using a force-displacement transducer and a polygraph recorder.

\section{Experimental protocol}

The preparation was allowed to stabilize for $15 \mathrm{~min}$ during which baseline twitch measurements were performed. Succinylcholine was then administered as an $i v$ bolus of 1 $\mathrm{mg} \cdot \mathrm{kg}^{-1}$, followed by an infusion at approximately 50 $\mu \mathrm{g} \cdot \mathrm{kg}^{-1} \cdot \mathrm{min}^{-1}$ and titrated to maintain approximately $50 \%$ suppression of the baseline twitch response. The concentration of the drug in the infusion solution was such as to allow infusion of about $1.5 \mathrm{ml}$ of infusate every hour. After a further $20 \mathrm{~min}$ of stabilization, cimetidine iv was administered into groups of two to three rats in a random order in doses of $3.2,7.5,10,17.8,23.7,31.6$ or 56.2 $\mathrm{mg} \cdot \mathrm{kg}^{-1}$. The selected doses were considered to be sufficient to show either zero or maximum effect and were chosen based on the concept of equally spaced log doses. ${ }^{8}$ Two blood samples, $0.35 \mathrm{ml}$, were withdrawn, one as close as possible to the time of the peak potentiation by cimetidine and the other when the potentiation by cimetidine had stabilized. After the observation of the entire cholinergic effect of cimetidine, approximately 20-25 min after cimetidine dosing, the infusion of suc- cinylcholine was discontinued to record the spontaneous recovery of the muscle twitch response. In another four rats, either 10 or $100 \mathrm{mg} \cdot \mathrm{kg}^{-1}$ cimetidine was given $i v$ but without any previous succinylcholine to determine whether cimetidine alone altered neuromuscular transmission.

\section{Measurements and calculations}

Cimetidine serum concentrations were determined using a modification (protein precipitation rather than liquid extraction) of a published reversed phase liquid chromatographic procedure. ${ }^{9}$ The coefficient of variation of the assay was 3.3 and $0.7 \%$ at 5 and $150 \mu \mathrm{g} \cdot \mathrm{ml}^{-1}$ respectively,

Cimetidine potentiation and reversal of succinylcholineinduced suppression of the twitch response was calculated as:

$$
\begin{gathered}
\begin{array}{c}
\text { Potentiation } \\
\text { of twitch } \\
\text { suppression } \\
(\% \mathrm{E})
\end{array} \\
\text { twitch height }
\end{gathered}=\frac{\begin{array}{c}
\text { Post-cimetidine } \\
\text { twitch height (at } \\
\text { peak or plateau } \\
\text { potentiation) }
\end{array}}{\text { Pre-cimetidine twitch height }} \times 100
$$

and

$\begin{gathered}\text { Reversal } \\ \text { of twitch } \\ \begin{array}{c}\text { suppression } \\ (\% \mathrm{E})\end{array}\end{gathered}=\frac{\begin{array}{c}\text { Pre-cimetidine } \\ \text { paralysis }\end{array}}{\text { Pre-cimetidine paralysis }} \begin{gathered}\begin{array}{c}\text { Post-cimetidine } \\ \text { paralysis } \\ \text { (at reversal) }\end{array} \\ \text { (a) }\end{gathered}$

These effects (either peak or plateau potentiation or reversal) were related to either the cimetidine dose administered or the cimetidine serum concentration measured using either a linear, $\log$-linear, an $E_{\max }$ or a sigmoid $E_{\max }$ (Hill) equation ${ }^{10}$ using the personal computer based nonlinear regression program PCNONLIN (Version 3.0, SCI Software, USA). For the reversal effect-serum concentration relationship this could only be done by use of the cimetidine concentration taken at peak potentiation since no concentrations were available at peak reversal. F-ratio tests were used to examine if the relationship between cimetidine's effect(s) and its serum concentration was statistically significant, realizing that this is not an entirely unbiased procedure when used with nonlinear equations. ${ }^{11}$ The appropriate equation that best described the effect of cimetidine was chosen by use of the F-ratio test, the Akaike Information Criteria, the Schwarz test and the Ip parameter. ${ }^{12} P<0.05$ was considered statistically significant for the linear equations but an exact significance value was not computed for the nonlinear equations. ${ }^{11}$ All data are presented as mean \pm SEM.

\section{Results}

Succinylcholine mean $( \pm$ SEM) infusion rate of $37.5 \pm 2.3$ 

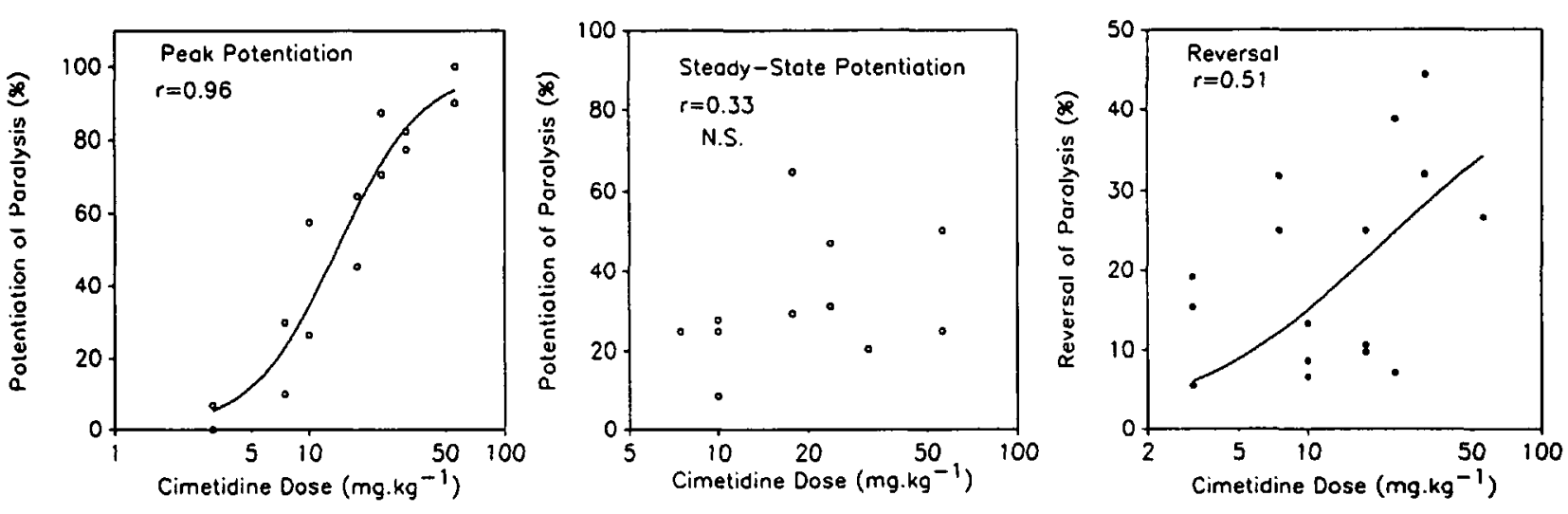

FIGURE 1 Muscle twitch recording in three rats illustrating the varied effects of $i v$ cimetidine. $1=$ baseline steady-state twitch suppression, 2 = peak potentiation, 3 = transient reversal, 4 = steady-state potentiation. At the first arrow cimetidine was administered and the succinylcholine infusion was discontinued at the second arrow.
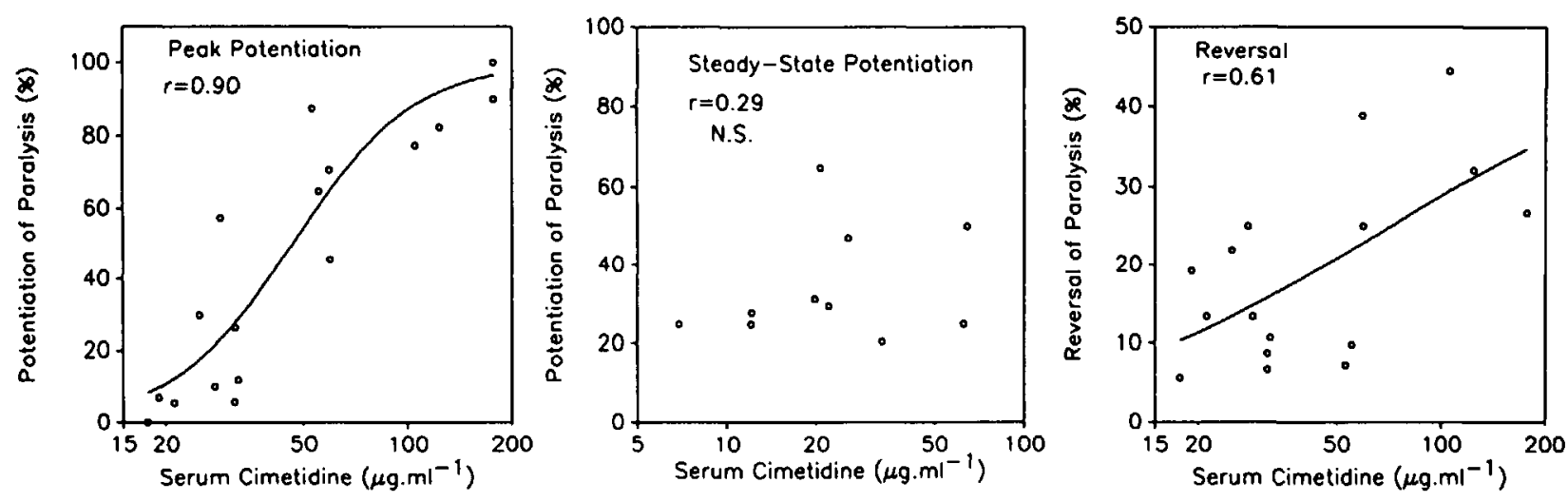

FIGURE 2 Relationship between cimetidine dose and its effect on succinylcholine-induced twitch suppression in rats. The relationship between peak potentiation and dose was most appropriately characterized by use of a sigmoidal $\mathrm{E}_{\max }$ (Hill) equation while that between reversal and dose was described best by an $E_{\max }$ model. There was no significant relationship between steady-state potentiation and dose.

$\mu \mathrm{g} \cdot \mathrm{kg}^{-1} \cdot \min ^{-1}$ produced $49.2 \pm 1.5 \%$ twitch suppression in 19 rats. When iv cimetidine was administered it produced an immediate potentiation of twitch suppression in all but two of the three rats receiving the lowest $(3.2$ $\mathrm{mg} \cdot \mathrm{kg}^{-1}$ ) dose of cimetidine. This was followed by a transient reversal of paralysis in all but two rats who received either a dose of 56.2 or $23.7 \mathrm{mg} \cdot \mathrm{kg}^{-1}$. A second phase of potentiation was then noted in eleven rats which persisted at steady-state or plateaued. This steady-state potentiation ranged from 9 to $65 \%$ and occurred in rats who received cimetidine doses ranging from 7.5 to 56.2 $\mathrm{mg} \cdot \mathrm{kg}^{-1}$. The onset of peak potentiation occurred in 19.0 $\pm 2.7 \mathrm{sec}$ after cimetidine dosing and the peak reversal was observed $4.1 \pm 0.4$ min after the doses of cimetidine. In the 11 rats where the potentiation persisted, it took 23.4 $\pm 1.5 \mathrm{~min}$ to stabilize. The first blood sample for cimetidine assay was taken $75 \pm 6 \mathrm{sec}$ after the cimetidine dose. Due to technical constraints, this sampling time was delayed by approximately one minute from the time of peak potentiation. Unfortunately, no cimetidine concentrations were available at peak reversal. The second cimetidine concentration was measured when the potentiation by cimetidine had stabilised (Figure 1).

There was a good relationship between the degree of peak potentiation of twich suppression by cimetidine and its dose and serum concentration respectively and the sigmoid $\mathrm{E}_{\max }$ (or Hill) equation was the most appropriate for characterizing these relationships. Potentiation at steady-state was not related to either the cimetidine dose or its serum concentration. However, there was an apparent relationship between the reversal of paralysis and the dose and serum cimetidine concentration respectively, although these relationships were not strong (Figures 2 and 3).

The cimetidine dose-producing $50 \%$ potentiation during its peak effect was $13.9 \pm 1.2 \mathrm{mg} \cdot \mathrm{kg}^{-1}$ and this 


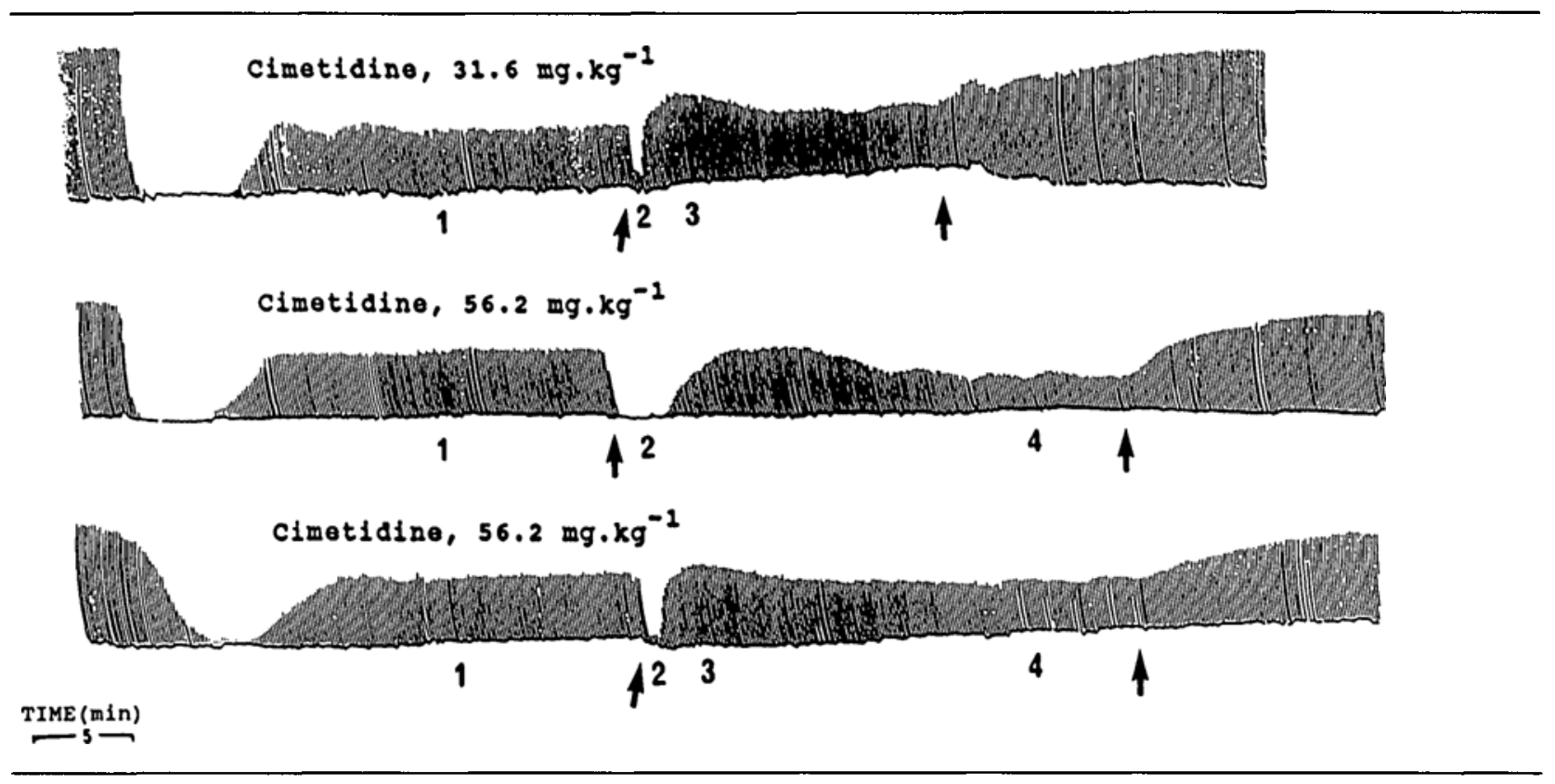

FIGURE 3 Relationship between serum cimetidine concentration and its effect on succinylcholine-induced twitch suppression in rats. The relationship between peak potentiation and concentration was most appropriately characterized by use of a sigmoidal $\mathrm{E}_{\text {max }}$ (Hill) equation while that between reversal and concentration was described best by an $\mathrm{E}_{\max }$ model. There was no significant relationship between steady-state potentiation and concentration.

effect was associated with a cimetidine serum concentration of $46.5 \pm 4.6 \mu \mathrm{g} \cdot \mathrm{ml}^{-1}$ (or $184 \pm 18.2 \mu \mathrm{M}$ ). Maximal reversal, of pre-cimetidine paralysis, was $46.8 \pm 17.5 \%$ and the concentration producing half maximal reversal was $62.5 \pm 46.6 \mu \mathrm{g} \cdot \mathrm{ml}^{-1}(248 \pm 185 \mu \mathrm{M})$. When cimetidine 10 or $100 \mathrm{mg} \cdot \mathrm{kg}^{-1}$ was administered alone to rats who had not received any succinylcholine, there was no effect on the normal (baseline) twitch response.

\section{Discussion}

Cimetidine produces three distinct cholinergic effects against the neuromuscular paralysis induced with the depolarizing agent succinylcholine. Peak potentiation of paralysis is followed by a rapid reversal which precedes plateau or steady-state potentiation. The predominant effect of cimetidine, however, is to potentiate the neuromuscular paralysis and the reversal is transient. This is supported by the observation that the relationship between peak potentiation and cimetidine serum concentration was easily discernable even though these concentrations were measured approximately one minute after peak potentiation. In contrast, reversal of paralysis was only weakly correlated to serum concentrations, although these concentrations were not determined exactly at the time of peak reversal. The results of this study support the hypothesis that iv cimetidine adversely affects neuromuscular function during anaesthesia, at least in rats.

The mechanism(s) responsible for the observed potentiation and transient reversal of neuromuscular paralysis by cimetidine is not clear from this study but may be a result of either a neuromuscular blocking effect of cimetidine itself or an anti-cholinesterase effect of the drug. Cimetidine has been shown previously in vitro to produce neuromuscular blockade but at very high (500-2000 $\mu \mathrm{g} \cdot \mathrm{ml}^{-1}$ ) bath concentrations. ${ }^{13}$ However, in the present study, cimetidine by itself at $100 \mathrm{mg} \cdot \mathrm{kg}^{-1}$ failed to affect neuromuscular transmission. This is not surprising since serum concentrations of cimetidine generated at this dose were only about $200 \mu \mathrm{g} \cdot \mathrm{ml}^{-1}$. Cimetidine also exhibits cholinesterase inhibition in vitro but again at high concentrations between 25 and $2500 \mu \mathrm{g} \cdot \mathrm{ml}^{-1}$ (100 to 10000 $\mu \mathrm{M}) .{ }^{14}$ Since succinylcholine depends on hydrolysis by cholinesterases for termination of its action, ${ }^{15}$ inhibition of this family of enzymes would either potentiate or reverse the action of succinylcholine. Potentiation by cimetidine would only be observed of course if cimetidine was able to inhibit the cholinesterase that breaks down succinylcholine more than the cholinesterase that metabolizes the endogenous transmitter acetylcholine itself. In this respect, it is important to note that cimetidine is a more potent inhibitor of acetylcholinesterase (AChE) than pseudocholinesterase (PChE) or butyrylcholinesterase (BuChE), ${ }^{14}$ the former being more specific for acetylcholine breakdown while the latter hydrolyzes succinylcholine. ${ }^{16}$ The potentiation of succinylcholine's effect by cimetidine may therefore result from an intrinsic neuromuscular blocking effect of cimetidine since inhibition of PChE or BuChE is weak. The transient reversal of paralysis by cimetidine may be 
mediated via AChE inhibition provided there is a mixed or phase II block present since succinylcholine is a competitive agent. Phase II (non-depolarizing or competitive) block would be reversed by increased acetylcholine concentrations resulting from $\mathrm{AChE}$ inhibition by cimetidine. The presence of a phase II block by succinylcholine could not be confirmed since the single-twitch response used here is unable to distinguish between a phase I and a phase II neuromuscular blockade.

Potentiation of succinylcholine by cimetidine may have clinical implications but in quantitative terms this interaction is not likely to be pronounced and probably will be unnoticed in anaesthesia practice since cimetidine doses used in patients are substantially lower than in this study. The serum concentrations (18 to $177 \mu \mathrm{g} \cdot \mathrm{ml}^{-1}$ ) that produce potentiation in rats are about 5 to 24 times higher than that noted ( 3.5 to $7.43 \mu \mathrm{g} \cdot \mathrm{ml}^{-1}$ ) in patients. ${ }^{17}$ In addition, with clinical premedication doses, cimetidine does not affect $\mathrm{PChE}$ or BuChE enzyme activity in vivo ${ }^{18}$ although higher than normal clinical concentrations (150-1500 $\left.\mu \mathrm{g} \cdot \mathrm{ml}^{-1}\right)$ decrease the PChE activity and succinylcholine hydrolysis rate respectively in vitro. ${ }^{18,19}$ Thus, caution will need to be exercised in patients who are otherwise at risk of displaying prolonged paralysis, for example, those with abnormal or low plasma cholinesterase enzyme activity or those receiving drugs that depress neuromuscular transmission. Patients with atypical cholinesterases may also be more susceptible to phase II block $^{20}$ which may add a further complication.

In conclusion, this study demonstrates that $i v$ cimetidine potentiates the neuromuscular blocking action of succinylcholine in vivo in rats. These results support reports of prolongation of succinylcholine blockade with cimetidine in patients.

\section{References}

1 Stoelting RK. Gastric fluid $\mathrm{pH}$ in patients receiving cimetidine. Anesth Analg 1978; 57: 675-7.

2 Scott RPF, Savarese JJ, Basta SJ, et al. Atracurium: clinical strategies for preventing histamine release and attenuating the haemodynamic response. Br J Anaesth 1985; 57 : 550-3.

3 Coombs DW, Hooper D, Colton T. Pre-anesthetic cimetidine alteration of gastric fluid volume and $\mathrm{pH}$. Anesth Analg 1979; 58: 183-8.

4 Gwee MCE, Cheah LS. Actions of cimetidine and ranitidine at some cholinergic sites: implications in toxicology and anesthesia. Life Sci 1986; 39: 383-8.

5 Kambam JR, Dymond R, Krestow M. Effect of cimetidine on duration of action of succinylcholine. Anesth Analg 1987; 66: 191-2.
6 Stirt JA, Sperry RJ, DiFazio CA. Cimetidine and succinylcholine: potential interaction and effect on neuromuscular blockade in man. Anesthesiology 1988; 69: 607-8.

7 Woodworth GE, Sears DH, Grove TM, Ruff RH, Kosek PS, $K a t z R L$. The effect of cimetidine and ranitidine on the duration of action of succinylcholine. Anesth Analg 1989; 68: 295-7.

8 Van Rossum JM. Cumulative dose-response curves II. Technique for the making of dose-response curves in isolated organs and the evaluation of drug parameters. Arch Int Pharmacodyn Ther 1963; 143: 299-330.

9 Kaka JS. Rapid method for cimetidine and ranitidine determination in human and rat plasma by HPLC. J Liquid Chromatogr 1988; $11: 3447-56$.

10 Holford NHG, Sheiner LB. Understanding the dose-effect relationship: clinical application of pharmacokineticpharmacodynamic models. Clin Pharmacokinet 1981; 6: 429-53.

11 Draper NR, Smith H. Applied Regression Analysis. 2nd ed., New York: John Wiley \& Sons Inc., 1981; 484.

12 Imbimbo BP, Martinelli $P$, Rocchetti $M$, Ferrari $G$, Bassotti $G$, Imbimbo $E$. Efficiency of different criteria for selecting pharmacokinetic multiexponential equations. Biopharm Drug Dispos 1991; 12: 139-47.

13 Galatulas l, Bossa $R$, Benvenuti $C$. Cimetidine induced neuromuscular blockade 'in vitro': antagonism by calcium. IRCS J Med Sci 1980; 8: 874.

14 Hansen WE, Bertl S. The inhibition of acetylcholinesterase and pseudocholinesterase by cimetidine. Arzneimittel-Forschung (Drug Research) 1983; 33: 161-3.

15 Chagas C, Sollero L, Suarez-Kurtz G. Synthetic neuromuscular blocking agents: absorption - distribution metabolism - excretion. In: Cheymol J (Ed). Neuromuscular Blocking and Stimulating Agents, Volume 1, 1st ed., Oxford: Pergamon Press Ltd., 1972; 409-23.

16 Foldes FF. Enzymes of acetylcholine metabolism. In: Foldes FF (Ed.). Enzymes in Anesthesiology, New York: Springer-Verlag Inc., 1978; 110.

17 Walkenstein SS, Dubb JW, Randolph WC, Westlake WJ, Stote RM, Intoccia AP. Bioavailability of cimetidine in man. Gastroenterology 1978; 74: 360-5.

18 Kambam JR, Franks JJ. Cimetidine does not affect plasma cholinesterase activity. Anesth Analg 1988; 67 : 69-70.

19 Cook DR, Stiller RL, Chakravorti S, Mannenhira T. Cimetidine does not inhibit plasma cholinesterase activity. Anesth Analg 1988; 67: 375-6.

20 Savarese JJ, Ali HH, Murphy JD, Padget C, Lee C, Ponitz $J$. Train of four stimulation in the management of prolonged neuromuscular blockade following succinylcholine. Anesthesiology 1975; 42: 106-11. 